\title{
The Capable Human Being and the Role of Language in Paul Ricoeur's Hermeneutical Philosophical Anthropology
}

Peter Emmanuel A. Mara

\begin{abstract}
Enhancing further the Socratic dictum, Paul Ricoeur maintains that "an examined life is a life recounted"-a principle that interprets the human being with a detour to the text, narrative, work of art, and discourse. Ricoeur believes that any philosophical understanding of the self presupposes a "text." Ricoeur's notion of the capable human being, therefore, precisely took shape from this hermeneutical approach to philosophical anthropology. This paper aims to inquire into the complex itinerary of Ricoeurean "hermeneuticalphilosophical anthropology." By hermeneutical-philosophical anthropology, we come to a full understanding of the philosophy of the human person by a textual or discursive interpretation (hermeneutics). The affirmation of the human person is reliant on how he understands himself through the works of literature and acts of language. Further, this paper attempts to elucidate Ricoeur's emphasis on the important role of the self, specifically the personalities of those who participate both in written literature and acts of verbal language, e.g., the author, the reader, the speaker, human reference, etc.
\end{abstract}

Key words: Ricouer, hermeneutics, language, capable human being

\section{Introduction}

7 he Western philosophical tradition has been engrossed with the articulation of the reality of the human person. Various schools of thought, philosophical trends and systems have inquired into different approaches to either affirm or deny this abundant reality. It is but apt to say that the philosophy of the West has been primarily attuned to the articulation and affirmation of the human individual with its attempt to conceive of human reality in relation to the self, the other, the World (society and institutions) and to the Supreme Being. In short, philosophy has been preoccupied in articulating the place of human beings in the world. ${ }^{1}$

${ }^{1}$ It may be proper to say that in the minds of Western philosophers, they have conceived of man as always in relation with other realities. Plato, in his Republic, starts from his 
Paul Ricoeur's philosophy aptly qualifies as pursuing precisely the question on the place of humans in the world. But in addition to this preoccupation with philosophical anthropology, Ricoeur maintains that any philosophical understanding of the self presupposes a "text." This a distinct approach in understanding the human being for it uses as a bridge not only the "other," but a written text, a work of art, a discourse. Ricoeur's notion of the "capable human being" precisely took shape from his hermeneutical approach to philosophical anthropology.

This paper aims to inquire into the complex itinerary of Ricoeurean "hermeneutical-philosophical anthropology." By hermeneutical-philosophical anthropology, we come to a full understanding of the philosophy of the human person by a textual or discursive interpretation (hermeneutics). The affirmation of the human person is reliant on how he understands himself through the works of literature and acts of language. Further, this paper attempts to elucidate Ricoeur's emphasis on the important role of personality, ${ }^{2}$ specifically the personalities of those who participate in written literature and acts of language, e.g., the author, the reader, the speaker, human reference (Other), etc.

\section{The Human Person in Discourse}

Ricoeur believes in the capacity of language to express human rationality and our inner character through its external signs and the meaning that it carries. Language bears a creative power which asserts the place of human beings in this world. However, problems are encountered when the language itself (as code) overpowers the person who speaks the language (as discourse). In this instance, the materiality of language as a set of codes and signs subdue the formal aspect, which is the meaning. In this dilemma, we are left to prevent the eclipse of the individual speaker, who has been suppressed by the structure of the language (as code) itself.

In studying the dynamic character of language, Ricoeur commences with the structural linguistic analysis of Ferdinand de Saussure. De Saussure distinguishes the structural model of language into two modes: namely, langue (language as code) and parole (language as discourse).

On the one hand, langue is the code or the set of codes, which has a collective character. It is a mode of language that is anonymous (nobody

principal idea that "a state comes into existence because no individual is self-sufficing; we all have many needs." Plato, Republic, in Great Political Thinkers: Plato to Present, ed. by W. Ebenstein and A. Ebenstein (Belmont, CA: Wadsworth Group/Thomson Learning), 37. It is clear in his statement, that what drives us to be related with the other is the need that we don't possess, which the other individuals do have. Meanwhile, Aristotle conceives of the human being as a political and social animal. He cannot but posit man except through its association primarily with the family, the village and ultimately, the state. Cf. Aristotle, Politics, in ibid., 86. The rest of Western philosophy follows from these conceptions.

2 By personality, I mean the entire reality of the human person or personhood. 
speaks), not intended, and unconscious. ${ }^{3}$ It is in this structure of language that the speaker is non-existent, for the one who speaks is submerged by the set of contemporaneous elements of the system of codes. Langue has its close affinity with scientific investigation, due to its systematic, compulsory nature, ${ }^{4}$ and its being a science of system which happens to be a synchronic linguistics, an approach which utilizes solely technical and exclusive language.

On the other hand, parole (language as discourse) safeguards the existence of the individual speaker. Unlike langue, parole bears the particular message which is rendered by the speaker. In this linguistic model, the individual is present for he has to say something to someone on something. It is situated in a temporal set of events, which characterize its diachronic character having a succession of arbitrary changes in time. It is in itself an event, a happening in time. With the emergence of the individual, the intention of the speaker is very well secured, for it is grounded in arbitrary and contingent condition of the message by the speaker. ${ }^{5}$

The dilemma which threatens the "eclipse of discourse" is forged by the privileging of the code over the discourse or the message, the system over the event, the structure over the intention, and the arbitrariness of the act for the systematicity of combinations within synchronic system. ${ }^{6}$

As Ricoeur goes beyond the linguistic model of Ferdinand De Saussure, he extends the terminology of parole, and switches it to discourse. He reveals that his "substitution of the term discourse for that of parole is intended to legitimate the distinction between semiotics and semantics as the two sciences which correspond to the two kinds of units characteristic of language, the sign and the sentence." 7 The involvement of semantics and sentence on this part is somehow parallel to the previous discussion of langue and parole. While semiotics is concerned with signs, which is directly similar to code, semantics is concerned with its message, sense and meaning. Semiotics is for langue as semantics is for parole. Therefore, the substitution of parole with discourse strengthens the distinction between the science of codes and the science of sense and meaning.

Ricoeur's view of language as discourse brings into emergence the invaluable role of the speaking subject and his reputation as somebody who's saying something to somebody on something. Discourse should be primarily understood as an event. "Something happens when someone speaks." event is somebody speaking. For Ricoeur, "language does not speak, people do." In this line of argument, he successfully transcends "the passage from a

${ }^{3}$ Paul Ricoeur, "Language as Discourse," in Interpretation Theory: Discourse and the Surplus of Meaning (Forthworth: Texas Christian University, 1976), 3. Hereafter cited as IT.

${ }^{4}$ Cf. ibid.

5 Cf. ibid.

${ }^{6}$ Ibid.

7 Ibid., 7.

8 Paul Ricoeur, From Text to Action (Evanston, Ill.: Northwestern University Press, 1991), 77. Hereafter cited as FTA.

${ }^{9}$ Ricoeur, IT, 12-13. 
linguistics of language or codes to a linguistics of discourse or messages," 10 which gives voice to the speaking subject. In this dimension, language is not anymore a set of signs, codes, and system which can be characterized as static, absolute, and fixed. Instead, language as discourse contains something, involves someone, refers to somebody, occurs somewhere, and happens in time. Discourse is realized temporally and in present. It refers to a speaker, whereby the emergence of the subject takes place. Language in this case, becomes self-referential that links to a person who speaks. ${ }^{11}$ On this part, Ricoeur upholds the role of the speaker, who is not submerged and overpowered by the system of codes; instead the speaker has the control over the language. Through discourse, there occurs a mediation of the self to itself.

Furthermore, since discourse is spoken by somebody, who is the human subject, there also occurs the affirmation of someone who is linked to the human subject while speaking. There comes the human referent, who is the other. The subject is speaking to somebody. This is again remarkable in Ricoeur, for he does not only privilege the speaking subject, but he affirms the existence of the other who has a vital role in the dialogue. The other neutralizes the monopoly of the speaking subject over the discourse. Without the human other, the speaking subject indulges only in monologue and soliloquies, which is unhealthy in discourse. Language as discourse then has the capacity to interconnect human beings, so language becomes the link between buman beings.

In a significant way, as Ricoeur seeks to unfold the complex reality of language, he further relates language to the authenticity and historicity of the speaking subject (and even the human referent) by positing the context and the setting of the spoken discourse. The speaking subject "refers to a world." Language becomes the mediation of the buman to the world and even to time. "Discourse refers to a world that it claims to describe, express or represent."12 The speaking subject of the discourse dwells in the world while articulating the language. Moreover, since it is an event, therefore it has a temporal character, which happens in human time.

To sum up this analysis, since the discourse is rendered primarily by the speaking subject, which points to its primal espousal, and it further points to the emergence of the human referent as its counterpart, it is, therefore, proper to assert that: the initial supposition of discourse is to safeguard the locus of the buman being in language. Although language is only but an external sign of the expression of the self, the precedent fact is that someone is uttering a meaning, not just alphabets, syllables and phonetics, but a sense that is thought of the human being a priori. Moreover, it significantly situates the human being as an authentic speaker, for it also posits the referentiality of discourse to the world, as a setting and dwelling of discourse, and time, which proves that it is an event of "saying something by somebody to someone on something." Language, as it is said, is an affirmation of human reality, which cannot exist outside the
${ }^{10}$ Ibid.
${ }^{11}$ Ibid.
12 Ricoeur, FTA, 78. 
human tongue. As Ricoeur points out, "language does not speak, people do," it is then a novel approach in viewing the human being, who has the capacity to say something. But upon saying something, he is directly connected with himself, also with the other, the world, and with time. One example to visualize this phenomenon is when one promises. For when one promises, he renders it to another person with whom he wishes it to fulfill; one also challenges time to keep what has been said for a long duration. But when one breaks a promise, one does not only fail the other and time, but one also betrays oneself and the institution of language. So in saying, one is also doing. It only goes to show that language is innately connected with the human being, no matter how crucial the system of grammar, semiotics, phonology, and codes are, the bottom line is that the human being has to, and could say something. And this very saying is the affirmation of himself and the human other as subjects who have the capacity to exploit language.

\section{The Human Person in Written Text}

Discourse, however, cannot be entirely monopolized by speaking. More than spoken language, discourse should be inscribed into writing. Ricoeur proposes that there should be a shift of medium from spoken language to written text, or from speaking to writing. It is because, in writing, there is "a full manifestation of something that is in virtual state in living speech, namely the detachment of meaning from the event."13 By spoken discourse, the event is temporally present, but beyond the event the meaning endures. For Ricoeur, "we understand the event insofar as it is transient, but its meaning is articulated."14 We cannot transcribe the eventuality of discourse, but only the meaning that endures beyond time. He further argues, "writing may rescue the instance of discourse because what writing actually does fix is not the event of speaking but the said of speaking... What we write is the meaning of the speech event, not the event as the event." 15 In other words, the act of writing puts priority to the meaning over the eventuality of discourse. But how does the human being emerge from the written text?

Ricoeur believes that "writing renders autonomous with respect to the intention of the author. What the text signifies no longer coincides with what the author meant." 16 This idea gives rise again to the eminent role of the human beings in the written discourse, as the one who writes the text and the one who reads it. They are two different entities with independent and exclusive conditions. It is indeed presumable that a written text came into existence because of the human ingenuity of the author, which is intended to be encountered by the curious reader via literature. Apart from the text, these characters in the written discourse are the key players in Ricoeur's theory of interpretation.

\footnotetext{
13 Ricoeur, IT, 26.

${ }^{14}$ Ibid., 12.

15 Ibid., 27.

${ }^{16}$ Ricouer, FTA, 83.
} 


\section{The Author}

Whenever a written work of discourse comes into existence, the author defines the individuality of the work. ${ }^{17} \mathrm{~A}$ text becomes distinct because there is somebody unique who creates it - i.e., the author. For Ricoeur, "the author is the artisan of the works of language." The singularity of the work refers as well to the singular configuration of the author. ${ }^{18}$ There is a certain signature that is left in the work of art that defines it to be somebody's creation. ${ }^{19}$ One can attribute a certain creation to an artist because of the individuality and uniqueness that is stamped on the work.

The author is the source of the written text, which is based on his own experiences, actions, and situation. Textual creation is sourced from one's personal, subjective and private intentions, and Ricoeur respects the personal motives of the author and the reasons behind the work. In trying to establish this approach of interpretation, he argues against the Romantic supposition the propaganda of which is "to understand an author as well as and even better than he understands himself" 20 and firmly upholds the selfhood of the author. Ricoeur writes: "an essential characteristic of a literary work is that it transcends its own psychosociological conditions of production and thereby opens itself to an unlimited series of readings, themselves situated in different socio-cultural conditions." 21 In his interpretation theory, he advocates a multiplicity of readings based on the life-situation of the reader. The text becomes autonomous from the authorial intentions and motives as soon as the text is transcribed or published. Ricoeur does not murder the author in this sense; he is just affirming the author's capacity to create a text, and that the mere attempt to write opens the possibility of a work to be read by a wider audience. Hence, Ricoeur strikes the balance in interpretation: while a text is created under the psycho-sociological condition of the author, this fact should not impede the interpretation of the reader. "The de-psychologizing of interpretation does not imply that the notion of authorial meaning has lost all significance." 22 The author is as important as the reader; therefore, no one must have the right to override one over the other in interpretation.

The profound explanation of this principle is imparted in the threefold mimesis, the itinerary of Ricoeur in his interpretation theory, the three important loci of his hermeneutics. Namely, Mimesis ${ }_{1}\left(M_{1}\right)$ pertains to the domain of the lived-experiences by the author; Mimesis $2\left(\mathrm{M}_{2}\right)$ covers the entire text; and Mimesis $3\left(M_{3}\right)$ is relegated to the reader. Respectively, these three mimesis can be referred to as prefiguration, configuration, and refiguration.

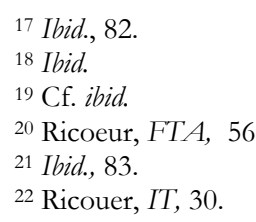


$\mathrm{M}_{1}$ considers the pre-philosophical stance of the written text through the lived-experience of the author. It is important to begin by understanding the context of the author's Lebenswelt - the pre-philosophical reality - in order to understand the text. Included in this task of pre-understanding is also to comprehend "what human acting is, in its semantics, its symbolic system, its temporality." 23 This allows one to be well-oriented with the selfhood of the author and his experiences condition. By attributing importance to the author $\left(\mathrm{M}_{1}\right)$ this way, one can then proceed to the configured text as created by the author.

\section{Text: World of Human Possibilities}

The text is an inanimate entity which is physically lifeless; but the text also contains meaning, sense and, most of all, many possibilities. It is a byproduct of human action, lived-experience and lived-world by the author, and it is where human beings, i.e., readers, could derive their own most possibilities. The text is a configured reality, a Mimesis, which brings about a triple mediation: "first, a mediation between individual events and the story taken as a whole; second, a mediation between factors as heterogenous as agents, ends, means, circumstances, chance or planned encounters and unintended results; and third, a mediation between an episodic chronological dimension and a configurating non-chronological dimension of action." 24 The configured details in a story are directly drawn from the various elements and factors that have occurred in the author's life. This assures the stamp of a human character in every story that a reader encounters.

In the text, life is configured as a literary work. For Ricoeur, "life has something to do with narrative. A life story characterizes the interval between life and death." 25 Upon reaching the reality of death, a life story underscores the various human possibilities that man possesses, which can be concretely articulated in a story through life's narrative identity, for "our life appears to us as the field of a constructive activity, borrowed from narrative understanding, by which we attempt to discover and not simply to impose from outside the narrative identity which constitutes us." 26 For him, "life is no more than a biological phenomenon as long as it has not been interpreted." 27 Our livedexistence must pass through the configuration of narrative, because it is also in this approach that we can understand our very life. It is through the attempt to recount the stories of our lives that we are brought closer to ourselves and to

23 Paul Ricoeur, Time and Narrative I (Chicago: University of Chicago Press, 1984), 64. Hereafter cited as TN $I$.

${ }^{24}$ Leovino Ma. Garcia, "Paul Ricoeur's Happy Memory, Remembering, Forgetting, Forgiving," in Thought the Harder, Heart the Keener: A Festschrift for Soledad S. Reyes, ed. by Eduardo Jose Calasanz et al. (Quezon City: Loyola Schools, Ateneo de Manila University: Office of Research and Publications, 2008), 6.

25 Paul Ricoeur, On Paul Ricoeur: Narrative and Interpretation, ed. by D. Wood (New York: Routledge, 1991), 20. Hereafter cited as PRNI.

26 Ibid., 32.

${ }^{27}$ Ibid., 27-28. 
our human condition. The succession of events that lead us to where we are can only be synthesized through a narrative story. Ricoeur casts out the fear of unfolding the story of one's life, because in such manner, it can be considered that one is worthy to live. He stresses that "if life can be understood only through stories that we tell about it, then an examined life is a life recounted." 28 This assimilated Socratic dictum goes beyond one's self-examination, but an interpretation of one's life-story: while Socrates proposes an introspective examination of one's life, Ricoeur interprets this Socratic examination of life through a narrative.

Ultimately, Ricoeur looks at the text as a locus of a vital interpretation of the possibility of being: "to understand a text is not to find a lifeless sense that is contained therein, but to unfold the possibility of being indicated by the text." ${ }^{29}$ Upon the encounter with a written text, we unfold the possibilities of our existence in front of it. We may consent to the possibility of emulating the antagonist and despise the protagonist in the text, or we may find some solutions to the problems we are facing in life as we read a text. Through this projection of our own most possibilities, a human being becomes intensely linked with the text, which could motivate, inspire, or discourage, for "to interpret is to explicate the type of being-in-the-world unfolded in the text... It is the projection of our own most possibility at the very heart of the situations in which we find ourselves." 30

\section{The Reader}

The reader fulfills and completes the interpretation theory of Ricoeur; through him, the refiguration of the meaning, sense, and reference of the text takes places. The reader tries to re-craft the text in the world that is dynamic, complex, and active. At this point, there comes a transition from the world of the text to the outside world, and Ricoeur refers to this domain as Mimesisz. It "marks the intersection of the world of the text and the world of the hearer or reader; the intersection, therefore of the world configured by the poem and the world wherein real action occurs and unfolds its specific temporality." 31 The reader is given the capacity of experiencing being-in-the-world and being-intime unraveled by the work. It is in the reader that meaning, sense, reference, etc. are fully actualized in the real world, for he is "the intersection between the world of the text and the world of the reader brings about Gadamer's fusion of horizons." 32 The territorial dominion of the reader is converged with the abundant world of text of the narrative; he is not given an absolute monopoly over one's subjective interpretation. The world of text neutralizes the scope of

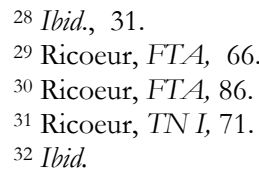


the reader, whereby both perspectives "intersect each other on the distant and at the open." 33

In reading written discourse, the reader is able to revive the referentiality of discourse, i.e., the ability to refer to something or somebody; for when a text is read, it immediately assumes the world and the temporality of the reader. It is not the case that the text has an "eclipse of reference," for there is an absence of common situation, unlike in a spoken discourse. Instead, reference is supplemented further by the reader through the "application of the present situation of the reader." ${ }^{34}$ Ricoeur writes:

The world is an ensemble of references opened up by every kind of text, descriptive, or poetic, that I have read, understood and loved. And to understand a text is to interpolate among the predicates of our situation all the significations that make a Welt out of our Umvelt. It is this enlarging of our horizon of existence that permits us to speak of the references opened up by the text or of the world opened up by the referential claims of most texts. ${ }^{35}$

To sum up, the role of the reader in a written discourse can be viewed in two ways: first, it brings forth the revival of the sense and meaning, and most especially, the reference of the text - and in doing so he fulfills the threefold loci of interpretation; second, this process is tempered and equalized by the presence of the written text itself. The reader has no absolute power in interpretation but is counterbalanced by the configured text, and fact of the pre-figured experience as well.

\section{Self-Understanding of the Human Being}

It has been pointed out that the core principle of Ricoeur is that in understanding oneself, one should recount the narrative of one's life. It is in this interpretation of a life-story that we become worthy to claim life, for "it must be said that we understand ourselves only by the detour of the signs of humanity deposited in the cultural work." 36 Unless one has gone through the entirety of symbols, signs, and the abundance of the narrativity of life, one is no more than a biological phenomenon. There is a deep and intense link between our life and symbols and signs, for we live through the expression of these symbolisms.

"To understand is to understand oneself in front of the text... It is exposing ourselves to the text and receiving from it an enlarged self..." 37 Our capacity to understand is measured so long as we hermeneutically understand

\footnotetext{
33 Ricoeur, FTA, 73

34 Ibid., 87.

35 Ricoeur, IT, 37.

36 Ricoeur, FTA, 87.

${ }^{37}$ Ibid., 88.
} 
ourselves in front of the text, as self-understanding is not independent of any elements. Thus, it relies on an exterior reality (which is also the expression of the experiences, actions of somebody, the author) so that the configured text is filled with a multiplicity of meanings. Ricoeur maintains that "the subject is never given from the start. [Instead], in place of an ego, enamored of itself arises a self-instructed by cultural symbols, the first among which are the narratives handed down in our literary tradition. And these narratives give us a unity which is not substantial, but narrative." 38 There is never a subject prior to the encounter with the text: a subject is a result of the fusion between oneself and the world of text.

Indeed, the philosophical inquiry of Ricoeur upholds the role of the human beings in discourse, be it written or spoken. In the task of interpretation, man does not only understand the text, but he also gains understanding of himself in front of the text. This unique affirmation of the selfhood links the human being with the external world, and consequently, of the many selves (author, reader, speaker, hearer, etc.) gain prominence. Likewise, interpretation does not discard any fact about life so that the humanistic principle affirms human life in a different fashion: by retelling one's story.

\section{Conclusion}

Don Ihde describes Ricoeur's version of hermeneutics as dialectical, for "a single perspective approach is insufficient to penetrate the insights needed, particularly for such topics as self-understanding or human ontology." 39 This paper supports this view: the dialectical (or dialogical) attitude of Ricoeur does not privilege one over the other and tries to strike a balance in his theory of interpretation. There is a constant equalizing attempt not to favor the author, the text, or the reader, giving each has its own locus, right, and privilege to speak. Consequently, this fair and equal weight among the three allows them to arrive at a multiplicity of readings, or polysemy of meanings. In this remarkable approach, the interpretation theory of Ricoeur ultimately achieves not only the understanding of the text, but along with it is the self-understanding of the reader. This approach of affirming the selfhood of the reader through the text is a novelty, so that "to understand is to understand oneself in front of a text." While a number of thinkers tried to pair the human being with external reality in order to affirm the self, i.e., Levinas: Other, Buber: Thou, Aquinas: God, Heidegger: World, Wojtyla: Human Action, etc.; Ricoeur pairs up the human being with a text, or discourse. For him, there is no direct knowledge of oneself. Instead, one must proceed to a detour to signs, symbols, narrative, stories, poetry, discourse, etc., in order to achieve self-understanding. Hence, this itinerary paved by Ricoeur greatly

38 Ricoeur, PRNI, 33.

39 Don Ihde, "Paul Ricoeur's Place in the Hermeneutic Tradition," in Philosophy of Paul Ricoeur, ed. by Lewis Edwin Hahn (Illinois: Open Court, 1994), 64. 
contributes not only to field of hermeneutics, but also to philosophical anthropology, for it propounds the notion of the human person in different instances animated with many possibilities.

Department of Philosophy, University of Santo Tomas, Philippines

\section{References}

Aristotle, Politics, in Great Political Thinkers: Plato to Present, ed. by W. Ebenstein and A. Ebenstein (Belmont, CA: Wadsworth Group/Thomson Learning).

Garcia, Leovino Ma., "Paul Ricoeur's Happy Memory, Remembering, Forgetting, Forgiving," in Thought the Harder, Heart the Keener: A Festschrift for Soledad S. Reyes, ed. by Eduardo Jose Calasanz et al. (Quezon City: Loyola Schools, Ateneo de Manila University: Office of Research and Publications, 2008).

Ihde, Don, "Paul Ricoeur's Place in the Hermeneutic Tradition," in Philosophy of Paul Ricoeur, ed. by Lewis Edwin Hahn (Illinois: Open Court, 1994).

Plato, Republic, in Great Political Thinkers: Plato to Present, ed. by W. Ebenstein and A. Ebenstein (Belmont, CA: Wadsworth Group/Thomson Learning).

Ricoeur, Paul, "Language as Discourse," in Interpretation Theory: Discourse and the Surplus of Meaning (Forthworth: Texas Christian University, 1976)

From Text to Action (Evanston, Ill.: Northwestern University Press, 1991).

, On Paul Ricoeur: Narrative and Interpretation, ed. by D. Wood (New York: Routledge, 1991). 1984).

,Time and Narrative I (Chicago: University of Chicago Press, 